\title{
Comparison of the Diet of Two Desert-living Owls, the Long-eared Owl (Asio otus) and Little Owl (Athene noctua) from Southern Mongolia
}

\author{
Dawn M. Scott, Karen Gladwin and Nigel Barton \\ Biology Division, University of Brighton, Cockcroft Building, Moulsecoomb, Brighton, \\ East Sussex, BN2 4GJ, UK.e-mail: dawn.scott@brighton.ac.uk.
}

\begin{abstract}
The diet of two sympatric owl species, the long-eared owl (Asio otus) and the little owl (Athene noctua) was investigated in an arid area of southern Mongolia using pellet analysis. In total 334 pellets of long-eared owl and 52 pellets of little owl were analysed, revealing the presence of five small mammal species (Dipodidae, three Muridae and one Soricidae), small birds and invertebrate fragments. Accumulative composition plots indicated a batch size of $35-60$ pellets was sufficient to reveal representative diet composition. Small mammals comprised the largest component of the diet of longeared owls with four species recorded, Phodopus was the most frequently occurring $(85 \%)$, followed by Meriones (33\%). Bird and invertebrate remains were also found in long-eared owl pellets but comprised less than $2 \%$. In contrast, invertebrates were the highest occurring component of the diet of little owls (35 $\%)$, with small mammals occurring in only $40 \%$ of pellets. Meriones was the most frequently recorded small mammal in little owl pellets $(23 \%)$ and contributed the greatest in terms of overall rodent biomass. There was a highly statistically significant difference in the diet of the two species $\left(\div^{2}=2043\right.$, d.f. $=4$, $P$ $<0.001)$. Levin's measure of niche breadth was greater for little owls $(0.71)$ than long-eared owls $(0.51)$, but overall the two species had low niche overlap using Levin's index $(0.22)$. These results are discussed in relation to previous findings of these two species.
\end{abstract}

Key words: desert, diet, little owl, long-eared owl, Mongolia, niche

\section{Introduction}

The competitive exclusion principle states that two species with identical requirements cannot coexist in the same place, at the same time (Gause, 1934). Competition will occur between species that overlap in their resource requirements. One mechanism of species coexistence is differences in feeding ecology, such as predatory behaviour and/ or dietary separation (Capizzi et al., 1998; Csermely et al., 2002). A species dietary range can be expressed in terms of niche width, and evidence of competition and/or diet separation can be investigated by examining the niche overlap between two species (Levins, 1968).

Twelve species of owl (Strigiformes) have been recorded in Mongolia (Fomin \& Bold, 1991), however they have not been subject to intensive studies and little is known about their ecological requirements such as diet (Batdelger, 1994, 2001). The long-eared owl (Asio otus) and little owl (Athene noctua) are two sympatric species found in Mongolia, which can coexist in a range of habitat types (e.g. Navarro et al., 2003; Martinez \& Zuberogoitia, 2004). Previous investigations into the trophic niche of these species have indicated that the dietary niche overlap between these two species is intermediate, between $30-60 \%$ (Navarro et al., 2003). The long-eared owl is a widely distributed medium sized owl, found throughout central Asia, Europe, North Africa and North America. It inhabits a wide range of habitat types, from woodlands (e.g. Tome et al., 2004) to deserts (Brown, 1995). It is known to require a mosaic of wooded and open habitats, for roosting and hunting respectively (Klippel \& Parmalee, 1982). In Europe the long-eared owl has been described as a restricted feeder specializing on mammals, which can make up to $80-98 \%$ of its diet (Marti, 1976; Cecere \& Vicini, 2000). However, studies have also demonstrated a wider range of prey items, including small birds and bats (Speakman, 1991; Cecere \& Vicini, 2000; Navarro et al., 2001). The study of Bertolino et al. (2001) in Italy described it as being "an adaptable predator that expands its food niche in the presence of diversified prey". In the North 
American deserts the long-eared owl was described as an opportunistic forager, feeding on a wide range of mammal species including rabbits (Sylvilagu sp.) and hares (Lepus sp.) (Craig et al., 1984).

The little owl, the smaller of the two species, also inhabits a wide range of environments from open habitats, such as steppe (Navarro et al., 2003), to rocky areas and desert (Obuch \& Kristin, 2004). However, in contrast to long-eared owls this species strongly avoids wooded areas and prefers open grassland for foraging (Kitowski \& Kisiel, 2003). It has been shown to be largely insectivorous, with over $50 \%$ of the diet being comprised of invertebrates in northern Italy (Gotta \& Pigozzi, 1997). However in terms of biomass, the diet is dominated by small mammals (Capizzi \& Luiselli, 1996; Goutner \& Alivizatos, 2003) and it will also take small birds (Obuch \& Kristin, 2004). Several authors have described its diet as opportunistic, reflecting temporal variations in prey availability (Goutner \& Alivizatos, 2003).

The aims of this study were to i) assess the summer diet of two desert-living owl species, ii) investigate dietary width and overlap between the two species to assess competitive pressure and coexistence mechanisms and iii) compare these findings with previous studies to investigate the impacts of locality on the diet composition.

\section{Materials and Methods}

The study was conducted between June and July 2004 in the arid Little Gobi Strictly Protected Area ' $A$ ', in southern Mongolia. Climate in this area is continental with winter temperatures dropping to $10^{\circ} \mathrm{C}$, and summer temperatures up to $40^{\circ} \mathrm{C}$. Annual rainfall is less than $50 \mathrm{~mm}$, and mainly falls between July and August. Habitat types in the area include rocky outcrops, sparsely vegetated gravel plains and meandering wadis dominated by Tamarix sp. and Haloxylon ammodendri.

Four batches of pellets were collected from roosting sites of each species within a $3 \mathrm{~km}$ zone surrounding $\mathrm{N} 42^{\circ} 11^{\prime} 30^{\prime \prime}$ and E $105^{\circ} 20^{\prime} 40^{\prime \prime}$. From the four individual long-eared owl roosts, 124, 100, 71 and 39 pellets were collected, and from the little owl roosts, batches of $8,9,13$ and 22 pellets were collected. Pellets were analysed separately, using only complete pellets, with prey species being identified using the skull and/or dentaries. The total number of individual prey items in the pellet was determined using the total number of dentaries or skulls, whichever was greater (Yalden \& Morris, 1990). Pellets with skulls present that could not be identified due to extensive damage or partial recovery were excluded from the analysis. Prey items were categorised into small mammals, birds or invertebrates. Species were identified to genus where possible by comparing skulls to a museum reference collection.

To confirm small mammal species present in the area, opportunistic live trapping was undertaken using Sherman traps $(23 \mathrm{~cm} \times 9 \mathrm{~cm} \times 7.5 \mathrm{~cm})$. For the bipedal Dipodidae, hand capture with butterfly nets was undertaken whilst spotlighting at night (Scott \& Dunstone, 2000). These surveys were undertaken in representative habitats in parallel with the pellet collection. To determine the number of pellets required from a single roost site to assess the representative diet composition, accumulative average composition of pellets was plotted against increasing pellet sample size for each species. The point at which the graph stabilises and levels out is considered an appropriate sample size. The importance of each rodent species in the diet, in terms of biomass, was calculated using average body weight determined from live trapping; Meriones $=60 \mathrm{~g}$, Dipus $=80 \mathrm{~g}$, Cricetulus $=45 \mathrm{~g}$ and Phodopus $=15 \mathrm{~g}$. Species biomass was multiplied by the number of individuals found within each pellet. Overall biomass contribution per rodent species was then summed for all pellets and expressed as a percentage. Niche was determined by calculating Levin's measures of niche breadth for each species and Levin's index of niche overlap between the two species based on percentage frequency occurrence data (Waite, 2000). A chi-squared test was applied to test the difference in diet composition between the two owl species.

\section{Results}

All roost sites for long-eared owls were in trees close to, or on the edge of, a riverbed. Roost sites appeared to be extensively used, with numerous pellets (over 400 pellets were found at one roosting site). Little owl roosting sites were more difficult to locate, usually amongst rocky outcrops with relatively fewer pellets found per site. A total of 334 pellets were analysed for long-eared owls and 52 pellets for little owls. Prey items found within the diet were Dipodidae (Dipus sagitta), three species of Muridae (Cricetulus migratorius, 
Phodopus roborovskii and Meriones meridianus), one species of Soricidae, birds, and invertebrates (which included solifuges (Galeodes galeodulus)). Twenty-one percent of little owl pellets had no skulls or identifiable remains present. Accumulative composition plots (Fig. 1 and Fig. 2) indicated a batch of 60 or more pellets was sufficient to provide a representative composition of diet for long-eared owls inhabiting this area, but fewer pellets (35 or more) were required for little owls. As a consequence of these findings, all pellet data from little owl roosts were pooled to enable dietary comparisons with the long-eared owl.

Figure 3 shows that small mammals comprise the largest component of the diet of long-eared owl. Phodopus was the most frequently occurring small mammal (in $85 \%$ of pellets) followed by Meriones (in $33 \%$ ). All other prey items and small mammal species occurred in less than $5 \%$ of long-eared owl pellets. In terms of overall rodent biomass (Fig 4.), Phodopus contributed the greatest, but was closely followed by Meriones. In contrast, invertebrates were the highest occurring component of little owl $\operatorname{diet}(35 \%)$, with small mammals occurring in only $40 \%$ of pellets. Meriones was the most frequently recorded small mammal in little owl pellets $(23 \%)$ and contributed the greatest in terms of overall biomass. Based on our derived data on body weights, the average biomass of a small mammal taken by long-eared owls was $25 \mathrm{~g}$, compared to $56 \mathrm{~g}$ for little owls. There was a highly statistically significant difference in the diet of the two species $\left(\div^{2}=2043\right.$, d.f. $\left.=4, \mathrm{P}<0.001\right)$. Levin's measure of niche breadth showed little owls to have a greater

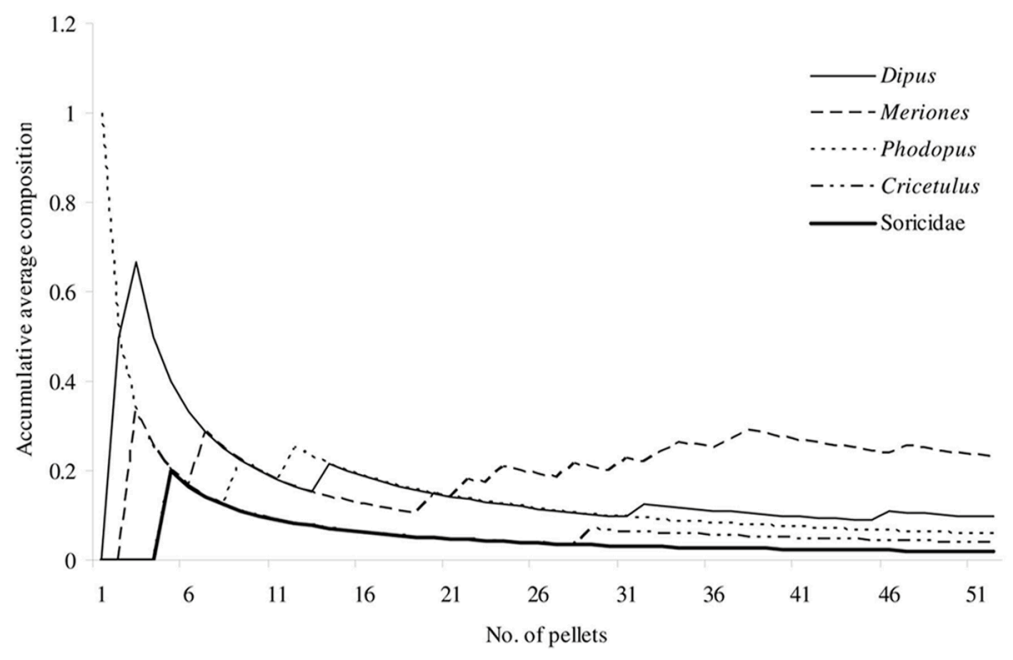

Figure 1. Plot of accumulative average dietary composition with increasing pellet sample size from four pooled little owl (Athene noctua) roosts.

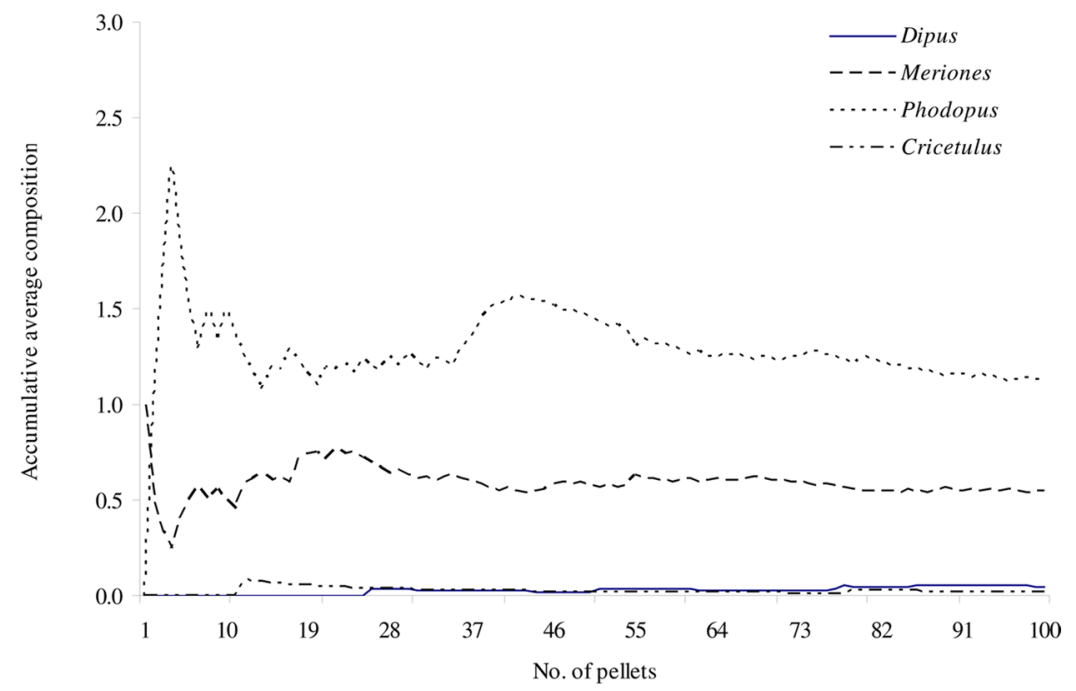

Figure 2. Plot of accumulative average dietary composition with increasing pellet sample size from one batch of pellets from a single long-eared owl (Asio otus) roost. 


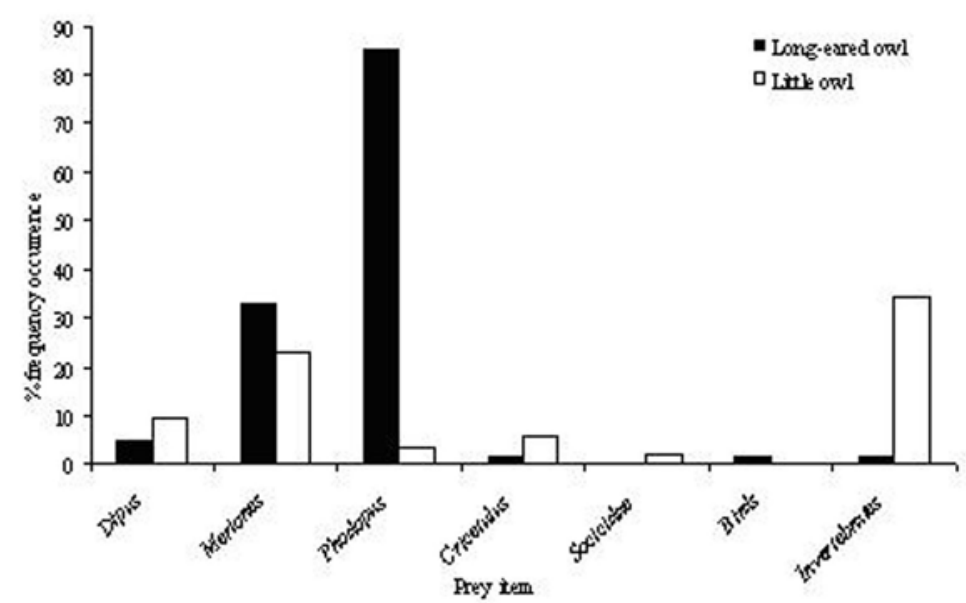

Figure 3. The percentage frequency of occurrence of prey items in the diet of long-eared owls and little owls in a desert region of Southern Mongolia.

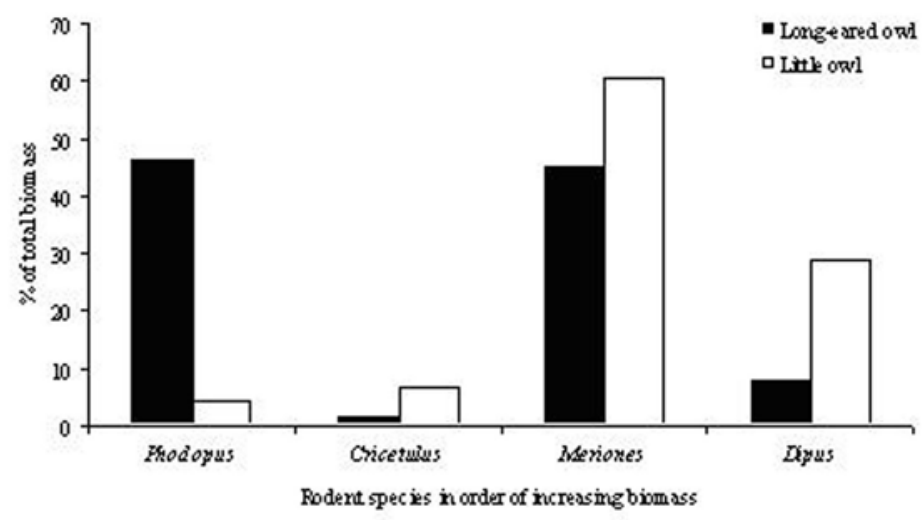

Figure 4. Relative importance of each rodent species in the diet of long-eared owls and little owls, expressed in terms of percentage of total rodent biomass.

niche breadth than long-eared owls $(0.70$ as opposed to 0.51 ), but overall the two species had a low level of niche overlap using Levin's index $(0.22)$.

\section{Discussion and Conclusion}

Our study showed little owls to have a greater niche breadth than long-eared owls. This difference was predominately due to the specialisation of longeared owls on a few species of small mammal, in contrast to the little owl which used a wider range of items more evenly. Long-eared owls are known to demonstrate selectivity of higher-ranking small mammal prey (Craig et al., 1985; Tome, 2003). Previous studies have also reported a wide dietary niche width for little owls and high prey diversity due to its common utilisation of invertebrate prey items as well as small mammals (Navarro et al., 2003; Goutner \& Alivizatos, 2003). Solifugae have also been found in the diet of little owls inhabiting desert regions (Obuch \& Kristin, 2004) however, contrary to other desert studies no Lacertidae were recovered from pellets in our study. We did find invertebrates in the long-eared owl diet but at very low occurrence. Little owls have been reported in some areas to be largely insectivorous (Obuch \& Kristin, 2004), with over $50 \%$ of their diet being comprised of invertebrates in northern Italy (Gotta \& Pigozzi, 1997). In our study invertebrates occurred in $35 \%$ of pellets. However in terms of biomass, the diet is dominant by small mammals (Capizzi \& Luiselli, 1996; Goutner \& Alivizatos, 2003). In our study no biomass data were derived for birds, invertebrates or Soricidae, therefore the importance of these prey items in the diet may be under or over estimated based on frequency occurrence data alone. When looking at our relative biomass of the rodent species, it is evident that Meriones is an important prey item for both little owls and long-eared owls. However, Dipus was found more frequently in the diet of little owls than long-eared owls and the inverse was true for Phodopus. The two species evidently utilise the 
available rodent prey base to different extents. Little owls have previously been reported to take Meriones, Cricetulus and Dipodidae in middleeastern and Asian deserts (Obuch \& Kristin, 2004).

Marks \& Yensen's study in 1980 found that most of the prey of long-eared owls weighed between 10 and $60 \mathrm{~g}$ and that prey over $100 \mathrm{~g}$ was less important in their diet. The mean weight of small mammals ingested in this study was not similar to previous findings. Due to their smaller body mass, little owls were expected to take smaller prey items than long-eared owls. In northern Italy, Gotta \& Pigozzi, (1997) found the average prey weight for little owls to be $22.3 \mathrm{~g}$. In our study the average prey weight was $56 \mathrm{~g}$, compared to $25 \mathrm{~g}$ for longeared owls. These data may reflect the relative abundance of prey in different habitat types; for example, low levels of Cricetulus recorded in the diet may reflect this species relative abundance and/ or its susceptibility to predation. However, these findings need further investigation.

From this and other studies it appears that habitat preferences, feeding behaviour and dietary separation are potential mechanisms for coexistence of these two sympatric species. Habitat selection of roosting sites was evident, with longeared owls preferring wooded areas whereas little owls preferred rocky outcrops, similar to the findings of Martinez \& Zuberorgoitia (2004). Dietary partitioning was evident in this study from low niche overlap (0.22), which has also been shown in phylogenetically related owl species (Capizzi \& Luiselli, 1996). Sympatric owls also display species-specific specialisations in feeding and hunting behaviour techniques (Csermely et al., 2002).

Both owl species have been reported as opportunistic or adaptable predators (Bertolino et al., 2001; Goutner \& Alivizatos, 2003), with seasonal differences occurring in their diet in relation to physiological requirements and prey availability (Alivizatos \& Goutner, 1999; Tome, 1997, 2003). Long-eared owls have been shown to take more birds during the breeding season, which is reflected in their seasonal niche breadth (Bertolino et al., 2001). Additionally, it is evident from the range of studies that diet also varies spatially. The distribution and diet of little owls can be affected by the surrounding landscape mosaic (Ferrus et al., 2002). Our study was only undertaken in one season, in one year and over a restricted area, therefore it only provides a snapshot of the diet of the two owl species studied. Further seasonal samples over a wider area would be needed to provide a more accurate picture of dietary composition and ecological requirements.

Our preliminary analysis suggested that the sample size was sufficient to give an indication of diet composition. Limited numbers of roosting sites and pellets from the little owl did not allow for investigations into individual differences in diet.

It is suggested from the number of individual owls sighted within the study area and the number of pellets recovered from roost sites that an individual little owl may have exclusive use of a roost site, whereas the long-eared owl roosts may be used communally (Holt, 1997). As no reference collection of skulls was collected from the site, skull remains were identified by comparison with museum specimens from other areas. No museum sample was available for Phodopus; therefore this was identified using available literature (Allen, 1940). All species identification should be confirmed by comparisons with local specimens.

\section{Acknowledgments}

We would like to thank all the students and staff from the National University of Mongolia that took part in the pellet analysis during the Steppe Forward Programme field trip 2004 to the Little Gobi Strictly Protected Area 'A'. We would also like to thank the National Park Authorities for permission to visit the site and the Harrison Institute, UK for aid with skull identification. The project was funded by the Darwin Initiative Steppe Forward Programme in collaboration with the Zoological Society of London and supported by the Mongolian Ministry of Nature and Environment.

\section{References}

Alivizatos, H. \& Goutner, V. 1999. Winter diet of the barn owl (Tyto alba) and long-eared owl (Asio otus) in northeastern Greece: A comparison. J. Raptor Res. 33: 160-163.

Allen, G.M. 1940. The mammals of China and Mongolia. Part 2. Publications of American Museum of Natural History. Central Asiatic Expeditions.

Batdelger, D. 1994. Conservation of Raptors in Mongolia: Current status and problems. $J$. Omithol. 135, Sonderheft: 214

Batdelger, D. 2001. Current Status and 
Conservation Problems of Birds of Prey in Mongolia. Oral presentation abstract, $4^{\text {th }}$ Eurasian Congress on Raptors, Seville.

Bertolino, S., Ghiberti, E. \& Perrone, A. 2001. Feeding ecology of the long-eared owl (Asio otus) in northern Italy: is it a dietary specialist? Canadian J. Zoology, 79: 2192-2198.

Brown N.L. 1995. Notes on the winter roost and diet of long-eared owls in the Sonoran Desert. J. Raptor Res. 29 (4): 277-279.

Capizzi, D. \& Luiselli, L. 1996. Feeding relationships and competitive interactions between phylogenetically unrelated predators (owls and snakes). Acta Oecologica, 17: 265284.

Capizzi, D., Caroli, L. \& Varuzza, P. 1998. Feeding habits of sympatric long-eared owl Asio otus, tawny owl Strix aluco and barn owl Tyto alba in Mediterranean coastal woodland. Acta Ornith. 33: 85-92.

Cecere, F. \& Vicini, G. 2000. Micromammals in the diet of the long-eared owl (Asio otus) at the W.W.F.'s Oasi San Giuliano, (Matera, South Italy). Hystrix 11 (2): 47-53.

Craig, T.H., Craig, E.H. \& Powers, L.R. 1984. Food habits of long-eared owls (Asio otus) at a communal roost site during the nesting season. Auk 102: 193-195.

Csermely, D., Casagrande, S. \& Sponza, S. 2002. Adaptive details in the comparison of predatory behaviour of four owl species. Italian J. Zool. 69: 239-243

Ferrus, L., Genot, J.C., Topin, F., Baudry, J. \& Giraudoux, P. 2002. Distribution of little owl (Athene noctua Scop.) at various scales of landscape analysis. Revue D Ecologie-la Terre et la Vie 57: 39-51.

Fomin, V.E. \& Bold, A. 1991. Catalogue of the birds of the Mongolian People's Republic. Nauka Press, Moscow. pp. 126.

Gause, G.F. 1934. The Struggle for Existence. Williams and Wilkins, Baltimore.

Gotta, A. \& Pigozzi, G. 1997. Trophic niche of the barn owl and little owl in a rice field habitat in northern Italy. Italian J. Zool. 64: 55-59.

Goutner, V. \& Alivizatos, H. 2003. Diet of the barn owl (Tyto alba) and little owl (Athene noctua) in wetlands of northeastern Greece. Belgian J. of Zool. 133: 15-22.

Holt, D.W. 1997. The long-eared owl (Asio otus) and forest management: A review of the literature. J. Raptor Res. 31: 175-186.

Kitowski, I. \& Kisiel, E. 2003. Distribution of little owl Athene noctua and barn owl Tyto alba in the Zamoœæ Region (SE Poland) in the light of atlas studies. Ornis Hungarica 12-13:1-2.

Klippel, W.E. \& Parmalee, P.W. (1982). Prey of a wintering long-eared owl in Nashville Basin, Tennessee. J. Field Ornith. 53 (4): 418-420.

Levins. R. 1968. Evolution in changing environments. Princeton University Press, Princeton, N.J.

Marks, J.S. \& Yensen, E. 1980. Nest sites and food habits of long-eared owls in southwestern Idaho. Murrelet 61: 86-91.

Marti, C.D. 1976. Review of prey selection by the long-earned owl. Condor 78 (3): 331336.

Martinez, J.A. \& Zuberogoitia, I. 2004. Habitat preferences for long-eared owls Asio otus and little owls Athene noctua in semi-arid environments at three spatial scales. Bird Study 51 (2): 163-169.

Navarro, J., Sanchez-Zapata, J.A., Carrete, M., Botella, F., Gavrilov, A., Sklyarenko, S., Donazar, J.A., Ceballos, O. \& Hiraldo, F. 2003. Diet of three sympatric owls in steppe habitats of eastern Kazakhstan. J. Raptor Res. 37 (3): 256-258.

Obuch, J. \& Kristin, A. 2004. Prey composition of the little owl Athene noctua in an arid zone (Egypt, Syria, Iran). Fol. Zool. 53, 65-79.

Scott, D.M. \& Dunstone N. 2000. Environmental determinants of desert-living rodent community structure in the north-east Badia region of Jordan. J. Zool. London 251:481-494.

Speakman, J.R. 1991. The impact of predation by birds on bat populations in the British Isles. Mammal Review 21(3): 123-142.

Tome, D. 1997. Diet composition of the long-eared owl (Asio otus) in central Slovenia - seasonal variation in prey use. J. Raptor Res. 28: 253258.

Tome, D. 2003. Functional response of the longeared owl (Asio otus) to changing prey numbers: a 20 year study. Ornis Fennica. 80: 63-70.

Tome, R., Bloise, C. \& Korpimaki, E. 2004. Nestsite selection and nesting success of little owls (Athene noctua) in Mediterranean woodland and open habitats. J. Raptor Res. 38: 35-46.

Waite, S. 2000. Statistical Ecology in Practice: A guide to the analysis of environmental and ecological field data. Prentice Hall. pp. 414.

Yalden D.W. \& Morris P.A. 1990. The Analysis of Owl Pellets. The Mammal Society, UK. 


\section{Хураангуй}

Монгол орны өмнөд бүс нутагт тархсан явлиг ууль (Asio otus), хотны бүгээхэй (Athene noctua) зэрэг хоёр симпатрик зүйлийн шар шувууны идэш тэжээлийн судалгааг гулгидасны задлан шинжилгээний аргаар судлав. Нийт явлиг уульны 334 гулгидас, хотны бүгээхэйний 52 гулгидас цуглуулан задлан шинжилгээ хийж 5 зүйлийн жижиг хөхтөн амьтан (1 зүйл Dipodidae, 3 зүйл Muridae, 1 зүйл Soricidae овгийн) болон жижиг шувууд, сээр нуруугүй амьтдын үлдэгдлийг илрүүлэв. Идэш тэжээл хуримтлагдсан газар нутагт 30-60 гулгидасыг судлахад түүнд агуулагдах идэш тэжээлийн бүрэлдэхүүнийг тодорхойлоход хангалттай болох нь тогтоогдов. Явлиг уульны идэш тэжээлийг бүрэлдэхүүний ихэнх хэсгийг 4 зүйлийн жижиг хөхтөн амьтан эзэлж буй нь тогтоогдсон бөгөөд, Podopus төрлийн амьтны үлдэгдэл хамгийн их тохиолдоцтой $(85 \%)$, түүний дараa Meriones төрлийн амьтны үлдэгдэл $(33 \%)$ мөн элбэг тохиолдож байв. Явлиг уульны гулгидсанд сээр нуруугүйтэн ба шувууны үлдэгдэл $2 \%$-аaс бага хэмжээгээр олдож байв. Харин үүний эсрэгээр хотны бүгээхэйний гулгидсанд сээр нуруугүй амьтдын үлдэгдэл хамгийн их хэмжээгээр (35\%) тохиолдож, жижиг хөхтөн амьтдын үлдэгдэл нийт гулгидасны дөнгөж $40 \%$-д нь илэрч байлаа. Хотны бүгээхэйний гулгидсанд Meriones төрлийн чичүүлний үлдэгдэл хамгийн их тохиолдоцтой $(23 \%)$ байсан бөгөөд гулгидаснаас илэрсэн нийт мэрэгчдийн “биомасс"-ын ихэнхийг бүрдүүлж байв. Энэхүу 2 зүйл шөний идэвхтэй махчин шувууны идэш тэжээлийн бүрэлдэхүүнд статистик шинжилгээ хийхэд ихээхэн ялгаатай болох нь илэрлээ $(\div 2=2043$, d.f. $=4, \mathrm{P}<0.001)$. Levin-ий хэмжүүрээр авч үзвэл хотны бүгээхэйний экологийн ниш буюу амьдрах орчин, амьдралын үйл ажиллагаа, идэш тэжээлийн бүрэлдэхүүний хамрах хүрээ г.м. үзүүлэлт (0.71) нь явлиг уульны экологийн ниш (0.51) буюу дээр дурьдсан үзүүлэлтээс илүү өргөн хүрээтэй болох нь илэрсэн юм. Гэвч Levin-ий индексээр харьцуулж үзвэл энэхүҮ 2 зүйл уульны экологийн нишийн давхцал харьцангуй бага (0.22) болох нь тогтоогдов. Энэхүү судалгааны үр дүнг дээр дурьдсан 2 зүйл уульны өмнөх судалгааны мэдээ баримттай холбон тайлбарласан болно.

Received: 18 May 2005 Accepted: 28 June 2005 